\title{
The 2009 Recovery Act: Directly Created and Saved Jobs Were Primarily in Government
}

Bill Dupor

Over one-half of the fiscal spending component of the American Recovery and Reinvestment Act (ARRA; i.e., the Recovery Act) was allocated via grants, loans, and contracts. Businesses, nonprofits, and nonfederal government agencies that received this type of stimulus funding were required to report the number of jobs directly created and saved as a result of their funding. Created and saved jobs represent, precisely, the full-time equivalent of jobs funded by first- and second-tier recipients of and contractors on ARRA grants, loans, and contracts. In this article, the author categorizes these jobs into either the private sector (businesses and nonprofits) or the government sector. It is estimated that at the one-year mark following the start of the stimulus, 166,000 of the 682,000 jobs directly created/ saved were in the private sector. Examples of private sector stimulus jobs include social workers hired by nonprofit groups to assist families, mechanics to repair buses for public transportation, and construction workers to repave highways. Examples of government stimulus jobs include public school teachers, civil servants employed at state agencies, and police officers. While fewer than one of four stimulus jobs were in the private sector, more than seven of nine jobs in the U.S. economy overall reside in the private sector. Thus, stimulus-funded jobs were heavily tilted toward government. (JEL E6, H7)

Federal Reserve Bank of St. Louis Review, Second Quarter 2014, 96(2), pp. 123-45.

I

n February 2009, the U.S. federal government began its largest anti-recession fiscal stimulus in over 70 years when it passed the American Recovery and Reinvestment Act (ARRA; i.e., the Recovery Act). ${ }^{1}$ The Congressional Budget Office (CBO)'s most recent assessment is that the cost of the Act will eventually total $\$ 821$ billion. $^{2}$ This article studies the employment effects of the stimulus using a new dataset. ${ }^{3}$

The data consist of legally mandated reports provided by the universe of awardees of stimulus funds. In particular, each recipient of a contract, grant, or loan was required to file a report every three months that included a self-constructed estimate of the number of jobs

Bill Dupor is an assistant vice president and economist at the Federal Reserve Bank of St. Louis. The author thanks John Childs for providing data collected by the Ohio Department of Education and Tim Conley, Duane Dupor, Bill Gavin, Matt Lewis, Mike McCracken, Stephanie Moulton, Jay Shambaugh, and David Wheelock for useful comments and conversations. Alex Bruner and Peter McCrory provided excellent research assistance. A repository containing government documents, data sources, a subject bibliography, and other relevant information pertaining to the Recovery Act is available at billdupor.weebly.com.

(c) 2014, The Federal Reserve Bank of St. Louis. The views expressed in this article are those of the author(s) and do not necessarily reflect the views of the Federal Reserve System, the Board of Governors, or the regional Federal Reserve Banks. Articles may be reprinted, reproduced, published, distributed, displayed, and transmitted in their entirety if copyright notice, author name(s), and full citation are included. Abstracts, synopses, and other derivative works may be made only with prior written permission of the Federal Reserve Bank of St. Louis. 
directly created and/or saved as a result of its stimulus funding, as well as a general description of these jobs. Created and saved jobs represent, precisely, the full-time equivalent (FTE) of jobs funded by first- and second-tier awardees of and contractors on ARRA grants, loans, and contracts. ${ }^{4}$

Using these reports, I estimate that at the one-year mark of the program, 166,000 of the 682,000 jobs directly created or saved by the Act were in the private sector. Thus, fewer than one of four stimulus jobs were in the private sector. In contrast, more than seven of nine jobs in the U.S. economy overall reside in the private sector. ${ }^{5}$

To my knowledge, this article is the first that uses direct survey evidence to assess how many private sector and government jobs were funded by the Recovery Act. Recent years have seen an ongoing public debate on the differences (or lack thereof) of the stimulative effects of the two types of employment.

While limited in quantity, the direct creation/saving of private sectors jobs was not trivial. For example, the U.S. Department of Transportation administered ARRA projects that directly created and saved thousands of private sector jobs, most of which were in the depressed construction industry; however, transportation jobs made up less than 5 percent of all jobs reported in this period.

This article provides an empirical contribution to the debate on the ability of the government to stimulate the private economy, with particular focus on jobs. One view expressed in this debate is that there is little difference between private and government employment. "'Spending is spending,' said Lawrence J. White, an economist at New York University's Stern School of Business. There is no difference in the multiplier effect from a private sector job or a public sector job" (see Jacobson, 2013). Similarly, in a discussion of the composition of jobs created by the Recovery Act, Blinder (2013, p. 226) writes, "Aren't government jobs jobs?"

An alternative view holds that, with respect to boosting the economy, jobs created in the private sector are likely to be more effective stimulus and that the government is ineffective at private sector job creation. In a letter to President Obama sent in February 2011, 150 economists from universities and research institutes signed this statement: "Efforts to spark private sector job creation through government 'stimulus' spending have been unsuccessful." The letter goes on: "To support real economic growth and support the creation of private sector jobs, immediate action is needed to rein in federal spending." 6 Along these same lines, Cohen, Coval, and Malloy (2011) find that state-level fiscal spending shocks, driven by changes in the seniority of various U.S. Congress members, caused a decrease in the corresponding states' corporate employment and investment.

The outcome that I document has a different flavor than the one predicted by advisers to President-elect Obama. On January 9, 2009, Jared Bernstein and Christina Romer wrote "More than 90 percent of the jobs created are likely to be in the private sector."7,8

My estimate is also different from at least one media report assessing the results of the stimulus. A Time magazine article from February 2010 entitled "After One Year, a Stimulus Report Card," states "about half of the jobs that the government counts as created by the stimulus were state- or local-government-funded positions" (Gandel, 2010). 
Analyzing the recipient-reported job creation data provides a new and distinct way to evaluate the stimulus. Other existing methods include aggregate time series analysis and crosssectional studies. Cross-sectional studies on Recovery Act spending have found a positive, statistically significant jobs effect; however, this job creation was very expensive. Wilson (2012) finds that increasing employment by one worker at the one-year mark of the Act cost $\$ 125,000$. Conley and Dupor (2013) find that, over the first two years following the Act's passage, it cost $\$ 202,000$ to create a job lasting one year. ${ }^{9}$ Given that the typical employment compensation (wages plus benefits) to a worker in a U.S. job is roughly $\$ 40,000$ per year, the benchmark point estimates from these studies suggest that the Recovery Act created/saved a job at a cost of roughly three to five times that of the typical compensation.

The recipient-reported data have an advantage over these other methods in that they do not require any identification or statistical modeling assumptions. Furthermore, this dataset is an analog to existing surveys that ask respondents how they would (or did) put a particular tax cut or rebate to use (e.g., spend or save the tax savings), such as Shapiro and Slemrod (2003, 2009). As with those approaches, the responses alone should not be interpreted as the program's entire aggregate effects. One reason is that they do not take into account general equilibrium effects of fiscal policy.

The recipient-reported data do suffer from a drawback that may be less significant in other approaches. The recipient-reported jobs are only those directly created/saved due to this federal spending. These data will tend to overstate true job creation if the direct government jobs crowd out private sector employment that would have occurred. On the other hand, these data will tend to understate true job creation to the extent that there are jobs "indirectly" created by the spending. Moreover, these data will not include the jobs created indirectly as a result of the tax cut and transfer component of the stimulus.

\section{BACKGROUND ON RECIPIENT-REPORTED DATA}

\section{Award Hierarchy and Definition of a Job Saved/Created}

The Recovery Accountability and Transparency Board (RATB) was created by the Act and one of the Board's responsibilities was to collect a wide variety of data from primary recipients, known as recipient reports. ${ }^{10}$ Primary recipients are one of the four "recipient roles" established by the Board. The other three are sub-recipients, primary vendors, and sub-vendors. Figure 1 illustrates the relationship between the roles. Primary recipients receive award funds from grants, loans, or contracts. Sub-recipients receive stimulus funds though the primary recipients. Vendors and sub-vendors sell goods and services to primary recipients and sub-recipients, respectively.

The responsibility for filing quarterly reports rested with the primary recipients. One required survey field that each recipient had to complete was titled "Number of Jobs." The RATB (2010, p. 19) contains a description of that data field: "Jobs created and retained. An estimate of the combined number of jobs created and jobs retained funded by the Recovery Act during the current reporting quarter in the United States and outlying areas." 11 The field 


\section{Figure 1}

\section{Award Hierarchy of ARRA Grants, Loans, and Contracts Administered by the Federal Government}

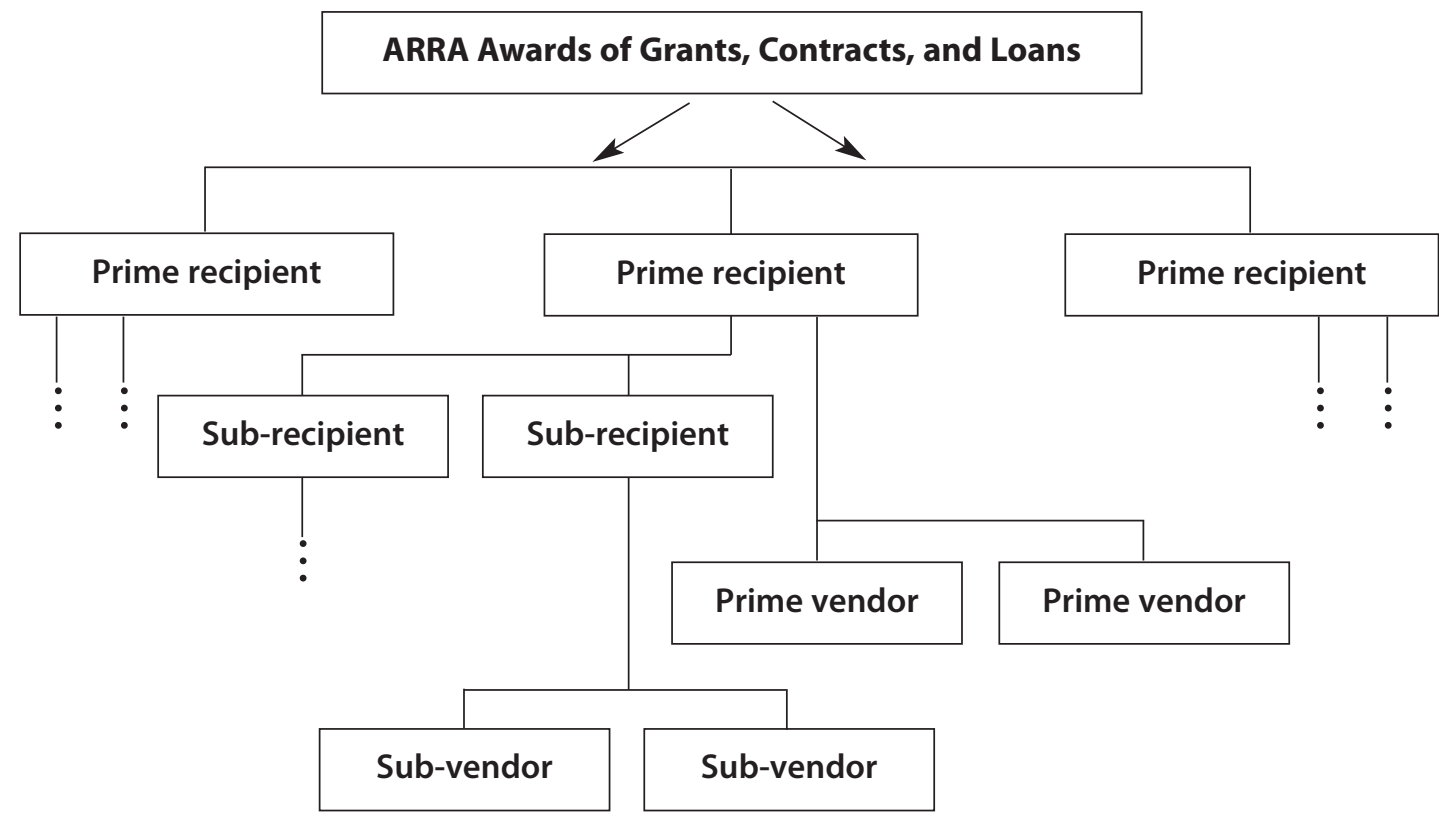

description goes on to say "For grants and loans, the number shall include the number of jobs created and retained by sub recipients and vendors." The Office of Management and Budget (OMB, 2009, p. 11) explains that, for grant and loan recipients, "the estimate of the number of jobs created or retained by the Recovery Act should be expressed as 'full-time equivalents' (FTE). In calculating an FTE, the number of actual hours worked in funded jobs are divided by the number of hours representing a full work schedule for the kind of job being estimated. These FTEs are then adjusted to count only the portion corresponding to the share of the job funded by Recovery Act funds."

A few examples are useful at this point. First, the Federal Highway Administration awarded a \$342 million Highway Infrastructure Program grant to the Wisconsin Department of Transportation. There were no sub-recipients of this award. There were three primary vendors: one construction firm and two engineering firms. In the fourth quarter of 2009, the Wisconsin Department of Transportation reported that the award had directly created/saved 51.1 jobs. It also reported that the project was less than 50 percent completed.

As a second example, the U.S. Office of Elementary and Secondary Education awarded a $\$ 480$ millon Education Fund grant to the state of Wisconsin, the primary recipient. The state of Wisconsin, in turn, distributed most of this money to over 400 local school districts, each of which was a sub-recipient of the original grant. In the fourth quarter of 2009, there were 
10 sub-vendors on the grant. These were due to expenses created by some sub-recipients to businesses, such as Apple Inc. for computers. At that time, there were no primary vendors, indicating that the primary recipient did not directly buy from vendors. In that quarter, the state of Wisconsin reported that the award had directly created/saved 3,951.56 jobs. With respect to data quality, the recipient-reported jobs data have been scrutinized by state and federal auditors, congressional committees, media organizations, and private citizens.

A Government Accountability Office (GAO, 2009) report based on the third-quarter recipient reports of that year did find some questionable data entries. For example, roughly 4,000 of the more than 100,000 recipient reports showed "no dollar amount received or expended but included more than 50,000 jobs created or retained." This 50,000 is not trivial, but it is relatively small compared with the 682,000 total jobs reported. In addition, there were " 9,247 reports that showed no jobs but included expended amounts approaching \$1 billion." In total, this $\$ 1$ billion represented less than 2.3 percent of the aid covered by these reporting requirements through the third quarter of 2009. The GAO report did not explore how many of these awards may have generated expenditures without creating jobs. Finally, the GAO found other reporting anomalies but stated that they were "relatively small in number."

The GAO report (2009) concluded with four recommendations to the OMB to improve the consistency of data collection and reporting. On its website, the GAO posted that two of its recommendations were adopted by the OMB though a December 2009 OMB memo to ARRA fund recipients. One major point of the OMB memo was that "the recipients will no longer be required to make a subjective judgment on whether jobs were created or retained as a result of the Recovery Act. Instead, recipients will more easily and objectively report on jobs funded with Recovery Act dollars." One of the two recommendations not adopted was moving to an hours worked, wages paid model instead of one of jobs created and saved. The other recommendation that was not adopted was that the "OMB continue working with federal agencies to provide or improve program-specific guidance to assist recipients, especially as it applies to the full-time equivalent calculation for individual programs."

Since the data I consider are from the first-quarter 2010 report, the RATB and OMB changes resulting from the GAO report may have improved the quality of reports. Unfortunately, the GAO has not issued a comprehensive follow-up (to its November 2009 analysis) of the recipient-reported jobs data. On this point, a GAO report (2011) specifically regarding U.S. Department of Energy ARRA funding did find that "the quality of FTE data reported by recipients to FederalReporting.gov has improved over time."

There have been relatively few cases of fraud in the recipient reports. Grabell $(2012$, p. 285) writes that the RATB received more than 7,500 complaints, which led to over 1,500 investigations. "Only about two hundred cases had resulted in criminal convictions, as of the fall of 2011."

\section{An Algorithm for Categorizing Job Types}

Neither the recipients nor the ARRA oversight board categorizes jobs into the private sector or the government sector; therefore, I perform this task using a three-step procedure as diagrammed in Figure 2. 
Figure 2 Algorithm for Determining Allocation of 100 Created/Saved Jobs Between Private Sector
and Government

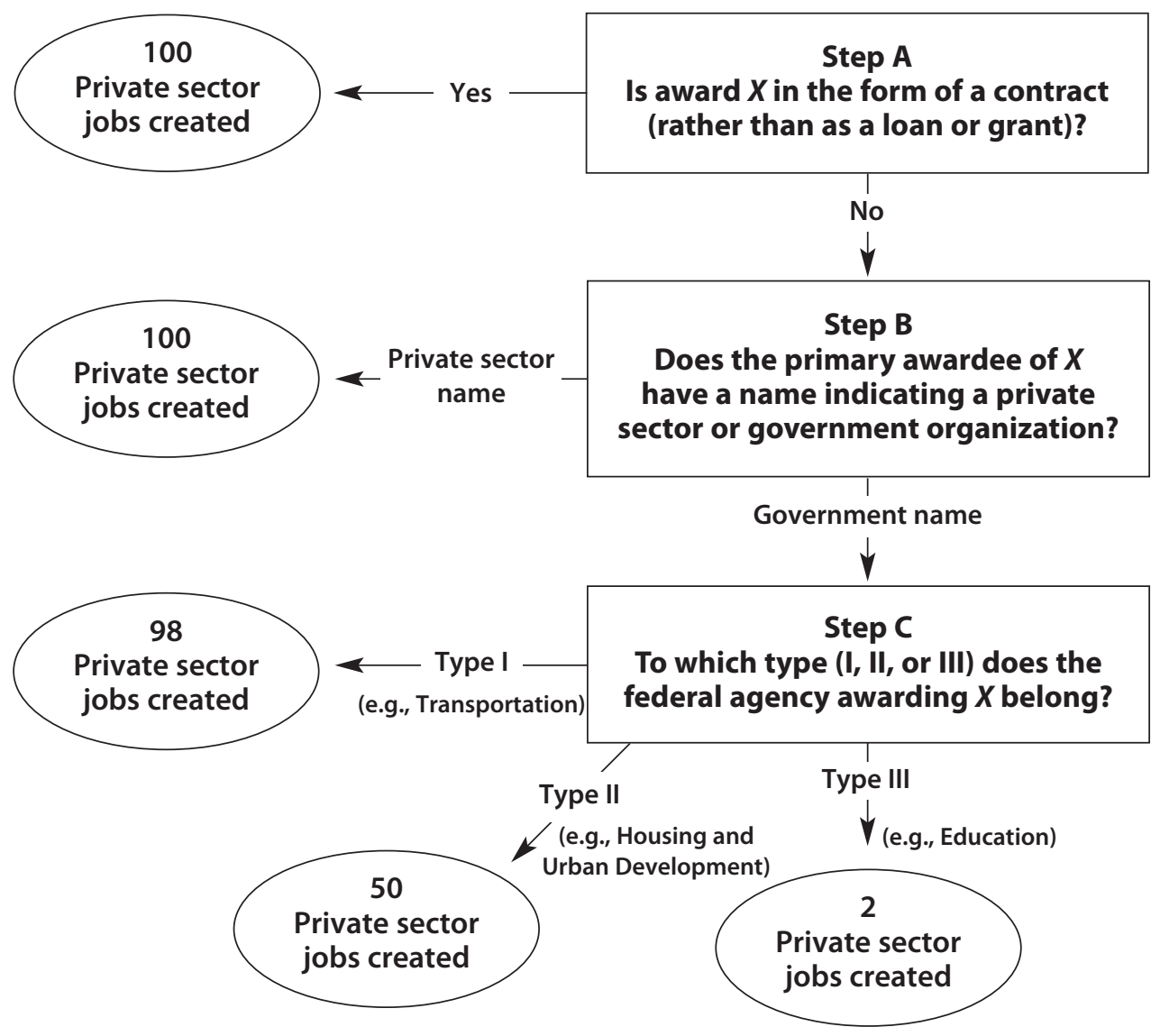

NOTE: See Tables A1 and A2 for common flags to indicate private and government primary awardees (applied in step B).

Step A. In the first stage (designated "Step A" in Figure 2), I assign all created/saved jobs that resulted from stimulus contracts (as opposed to grants and loans) as private sector jobs. My reason is as follows. Analysis of the contract data reveals that the stimulus contracts overwhelmingly were between an agency of the federal government and a private business.

Step B. In the second stage ("Step B"), I begin by sorting each remaining primary recipient into either a government organization or a private sector organization by using the recipient's name. Many recipients were assigned by searching within each name for "flags" (i.e., words and abbreviations) that indicate a government or private sector organization. For example, if "CITY OF" appears in a recipient's name, it is categorized as a government organization. If "CORPORATION" appears in a recipient's name, it is categorized as part of the private sector. Tables A1 and A2 in the appendix contain sample lists of flags used. If the primary recipient's 
name indicates a private sector organization, I assign all of this recipient's created/saved jobs to the private sector.

One choice I must make in this step is to define a government organization. An organization is treated as part of a government if operational control is by a person or persons serving in the role of a government official or by a person appointed by a government official or agency. The above definitions imply straightforwardly that teachers at public schools and employees at state agencies are part of the government sector. Public state universities, such as the University of Wisconsin, are treated as part of government as well because the operational control of a public state university may be in the hands of a private organization whose members are designated by a state government official. For example, a public university may be controlled by a board of regents (a private organization), but the regents are selected mainly by state government official(s), such as the state's governor.

This definition also clearly implies that private businesses are not part of the government sector. The ownership of a private company, and therefore its direct control, lies outside the hands of a government or government-appointed official. This is not to say that a nongovernment organization may not receive funds from the government. For example, although a private construction company may enter into a legal contract to create a highway for a state's department of transportation, the operational control of the organization is beyond the hands of government. Similarly, a charity, such as the United Way, may receive funding from a government, but my definition implies that it is not part of government. A private organization is any organization that is not part of government, which includes both businesses and nonprofits.

Approximately 1,750 recipients remained uncategorized after applying the above procedure. A research assistant and I split the task of manually assessing the status of each remaining recipient and assigning each to the private sector or government. This process almost always involved locating a website for the organization and reading its description and organization structure. After this manual assignment, 2.6 percent of created/saved jobs had not been categorized.

Step C. The third step ("Step C" in Figure 2) is an attempt to distinguish how many private sector jobs were created/saved through a grant or loan received by a primary recipient if the recipient is a government organization. Step $\mathrm{C}$ is necessary because a primary recipient can use its award to purchase goods or services from vendors and sub-vendors and also make subawards to sub-recipients. As explained above, only the primary recipient reports the jobs created/saved and this single number is the sum of jobs created/saved from the entire award. Vendors and sub-vendors are in the private sector and sub-recipients may also be in the private sector. ${ }^{12}$ If it is assumed that all jobs created by awards for which the primary recipient was part of government are government jobs, it might cause an understatement of the number of private sector jobs created/saved.

To address this issue, I examine in turn each federal agency responsible for awarding Recovery Act funds. Based on the awarding federal agency, I allocate the created/saved jobs between the government and private sector, which amounts to assigning each agency a "private sector percentage." I use three different private sector percentages: 98 percent (mostly private sector, or type I); 50 percent (one-half private sector, or type II); and 2 percent (limited 


\section{Table 1}

Percentages of Jobs Assigned to Private Sector*

\begin{tabular}{lll}
\multicolumn{1}{c}{$\begin{array}{c}\text { Type I } \\
\text { Mostly private sector (98\%) }\end{array}$} & $\begin{array}{c}\text { Type II } \\
\text { Half private sector (50\%) }\end{array}$ & $\begin{array}{c}\text { Type III } \\
\text { Limited private sector (2\% ) }\end{array}$ \\
\hline Department of Transportation & Department of Labor & Department of Education \\
Environmental Protection Agency & $\begin{array}{l}\text { Department of Housing and } \\
\text { Urban Development }\end{array}$ & $\begin{array}{l}\text { Department of Health and } \\
\text { Human Services }\end{array}$ \\
Forest Service & $\begin{array}{l}\text { Centers for Disease Control } \\
\text { and Prevention }\end{array}$ & Department of Justice \\
U.S. Army Corps of Engineers & & Administration on Aging \\
Department of Energy & &
\end{tabular}

NOTE: This list contains a sample of federal funding agencies. See Appendix A for a complete list of all federal agencies that funded ARRA-created/saved jobs. *For primary recipients of loans and grants that are government organizations, according to funding federal agency.

private sector, or type III). Table 1 separates some of the federal awarding agencies into the three categories. ${ }^{13}$

For example, I classify projects funded by the U.S. Department of Transportation as being mostly in the private sector (i.e., type I). This classification was made by examining grant descriptions and created/saved jobs descriptions from the recipient reports. The largest number of these jobs came in the form of grants from the Federal Highway Administration to state and local government agencies, which in turn contracted construction companies. Only a small number of jobs were saved/created from employment at the state and local government agencies that oversaw the projects. As a result, 2 percent of the jobs were assigned to government and 98 percent were assigned to the private sector. ${ }^{14}$

As a second example, I classify projects funded by the U.S. Department of Justice as being mostly in the government sector (i.e., type III). The U.S. Department of Justice administered Justice Assistance Grants (JAG) to states and some localities. In reading many descriptions of projects and the jobs those projects created from the recipient reports, I observed that nearly all of the jobs were in law enforcement, the courts, and jail coverage. In my reading of grant descriptions and created/saved jobs descriptions, there was a relatively small number of jobs resulting from hiring vendors and also from sub-recipient grants to nonprofits. As a result, the Department of Justice jobs were classified as type III.

My explanation for these categorizations for each of the main federal awarding agencies appears in Appendix A. Table A3 shows the entire list of awarding agencies and their associated types.

Summarizing the procedure, suppose a particular primary recipient records creating 100 jobs. Then, follow the steps below:

Step A. If the primary recipient's award is a contract (as opposed to a grant or loan), then its 100 jobs are assigned to the private sector; otherwise, proceed to step B. 


\section{Table 2}

Directly Created and Saved Jobs: Private Sector and Government

\begin{tabular}{lccc}
$\begin{array}{l}\text { Federal department/ } \\
\text { agency }\end{array}$ & Private sector jobs & Government jobs & $\begin{array}{c}\text { Percentage of } \\
\text { private sector jobs }\end{array}$ \\
\hline All & 162,567 & 504,784 & 24 \\
\hline Education & 17,859 & 456,062 & 4 \\
\hline Transportation & 32,569 & 626 & 98 \\
\hline Health and Human Services & 20,397 & 11,390 & 64 \\
\hline Energy & 21,501 & 460 & 98 \\
\hline Housing and Urban Development & 10,993 & 9,175 & 55 \\
\hline Labor & 8,738 & 7,967 & 12 \\
\hline Justice & 17,29 & 13,065 & 12 \\
\hline Environmental Protection Agency & 9,509 & 180 & 98 \\
\hline Agriculture & 5,318 & 164 & 97
\end{tabular}

NOTE: These numbers are based on first-quarter 2010 recipient reports by ARRA recipients of contracts, grants, and loans. I was unable to assign 2.4 percent of all created/saved jobs to either the private sector or government sector.

Step B. If the primary recipient has a name indicating that it is in the private sector, then its 100 jobs are assigned to the private sector; otherwise, proceed to step C.

Step C. If the primary recipient's award has a government name, then $X$ of its jobs are assigned to the private sector, where $X$ depends on the federal agency that funds the award. The remaining $100-X$ jobs are assigned to the government sector.

\section{DIRECTLY FUNDED JOBS PRIMARILY IN STATE AND LOCAL GOVERNMENT}

The top row labeled "All" in Table 2 shows the total number of jobs directly created/saved in the first quarter of 2010, which are then broken down into specific categories. These numbers and those later in the table do not include the 15,000 jobs (roughly 2 percent ) that my categorization procedure could not assign as either private or public.

Table 2 shows that about 163,000 of the 667,000 total assigned jobs were in the private sector, which is 24.4 percent of all assigned jobs. This article's headline finding is that saved/ created jobs were primarily in government.

As a sensitivity analysis, I consider an increase in the share of private sector workers in the three categories. For type I agencies, I increase the private sector share from 98 percent to 100 percent. For type II agencies, I increase the private sector share from 50 percent to 80 percent. For type III agencies, I increase the share from 2 percent to 12 percent. This modification implies that the percentage of private sector jobs created/saved was 31.2 percent, only slightly greater than the benchmark result. Thus, this adjustment to the model calibration does not overturn my main finding. 
For completeness, I report the numbers of jobs by sector in a way that does not drop the small number of jobs that were not assigned. To do so, I construct these numbers by assuming that the fraction of private sector jobs among the unassigned jobs equals the fraction of private sector jobs among the assigned jobs. Under this assumption, the number of private sector jobs is 166,000 among the 682,000 total jobs reported as created/saved. Regardless of whether unassigned jobs are included or excluded, the numbers are nearly identical. I report this adjusted number in this article's abstract and introduction.

Table 2 breaks down the number and type of jobs for the nine largest job-creating/-saving federal agencies. First, the Department of Education created the most total jobs of any agency. These jobs were heavily weighted toward government.

The Department of Education administered several of the Act's largest grant programs, including the Education Stabilization Fund and the Government Services Fund. These grants were for elementary and secondary education. Elementary and secondary education jobs are mainly in government. Furthermore, since local and state government revenues fell dramatically during the recession, the governments used the grants to cover budget shortfalls and pay their workers.

Also, the Department of Education administered the ARRA Government Services grants. These helped state governments meet payrolls of non-education workers.

The second-largest job-creating agency was the Department of Transportation. It created private sector jobs almost exclusively; however, the number of government jobs funded by the Department of Education dwarfed the number of private jobs funded by the Department of Transportation by a 14-to-1 ratio. Agencies within the Department of Transportation that specifically oversaw projects included the Federal Highway Administration, the Federal Transit Administration, and the Federal Railroad Administration. The largest source of Department of Transportation jobs resulted from the hiring of highway construction companies by states using funds from the Federal Highway Administration.

Recall that step $\mathrm{C}$ in the algorithm required categorizing federal agencies by their intensity of private versus government job creation. While Appendix A gives detailed explanations for the categorization for the larger agencies, I do not provide explanations for the categorizations I made for the relatively smaller agencies. Changing these categorizations has little quantitative effect on the results. For example, switching the type III agencies (for which assignment explanations are not detailed in the appendix) to type I agencies would increase the percentage of private sector jobs by only 2 percentage points (i.e., increase the percentage from 24 percent to 26 percent).

My finding that job support through Recovery Act funds occurred primarily in the government sector may help explain why the U.S. unemployment rate did not fall as predicted. ${ }^{15}$ By focusing on the government sector, the positive jobs effects of the Act were likely slanted toward the well educated. This is because roughly 49 percent of state and 47 percent of local government workers have at least a bachelor's degree, whereas for private sector workers this proportion is only 25 percent (see Greenfield, 2007). On the other hand, the labor market during the recession was much weaker for the less educated. In February 2010, the unemployment 


\section{Figure 3}

\section{Labor Market Conditions Before Recession and During Stimulus Period}

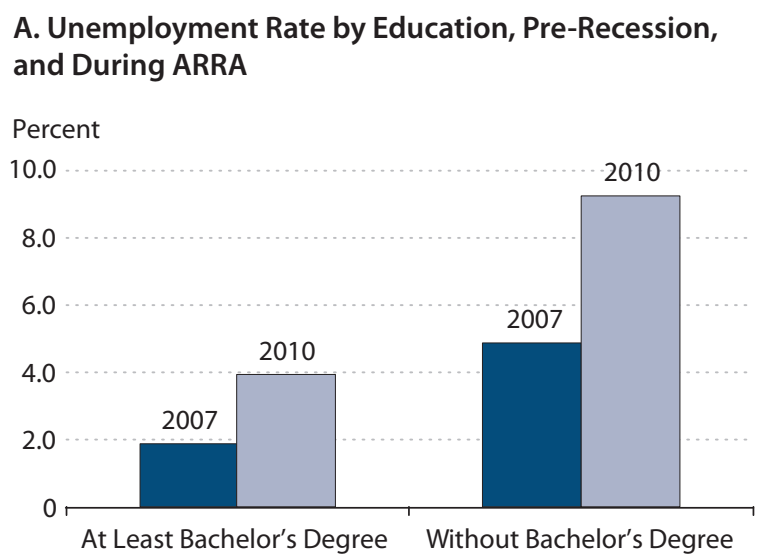

B. Job Posting Rate by Sector (February 2010)

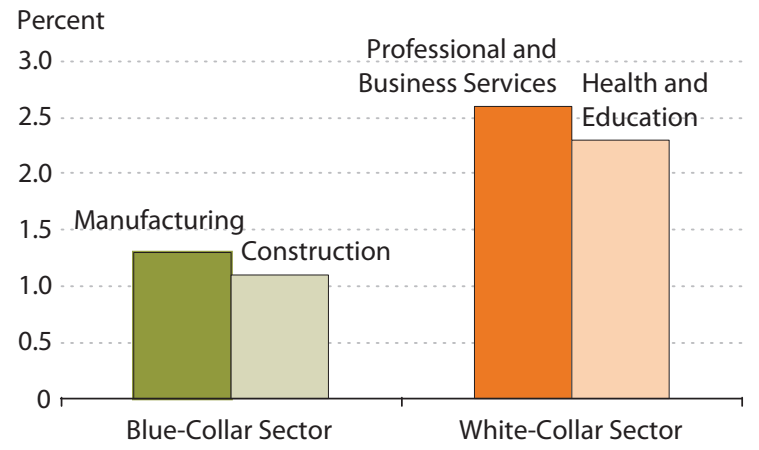

NOTE: Unemployment rates are for February and are restricted to those with at least a high school diploma. The job posting rate is the number of job openings divided by employment in the corresponding sector. Data are deseasonalized from the Bureau of Labor Statistics.

rate was 4 percent among persons with a bachelor's degree and over 9 percent among persons without (Figure 3A).

Moreover, on the supply side, job availability (that is, the job posting rate) for white-collar work was more than double that for blue-collar work during the downturn (see Figure 3B). Thus, the stimulus spending studied in this article may have largely missed that part of the labor market in most need of assistance. ${ }^{16}$

A common perception is that the Recovery Act had a strong infrastructure component, suggesting that large numbers of private sector construction (and related industry) jobs should have been created. Job creation through infrastructure spending was complicated by several factors. First, school districts had the option of using stimulus education funds to make capital improvements, which would have implied more infrastructure job creation. In the 2010:Q1 recipient reports, there was almost no U.S. Department of Education spending on infrastructure; schools instead used their stimulus funds to maintain and add to their payrolls and provide pay raises. Second, many programs with funds committed only to infrastructure spent those funds very slowly. For example, only 56 percent of the Act's $\$ 48.1$ billion transportation allocation had been spent at the two-year anniversary of the Act's passage.

\section{CONCLUSION}

A comprehensive understanding of the impact of the American Recovery and Reinvestment Act is far from complete; however, a growing body of research, taken together, appears to be forming a coherent picture of some of the effects of the stimulus. That is, while the stimulus 
was unsuccessful in creating/saving private sector jobs, it helped maintain and sometimes increase (i) state and local government services, and in turn public sector jobs, as well as (ii) transfer payments to the poor and unemployed. Each of the papers I describe next shows an element or elements that help shape the above picture of the stimulus.

Conley and Dupor (2013) use state-level data to conduct a cross-sectional study of the effect of stimulus jobs. They find that the Act resulted in a statistically significant increase in state and local government employment but not in private employment. Jones and Rothschild (2011), using their own surveys of grant, loan, and contract recipients, find that approximately one-half of the individuals filling positions directly created by Recovery Act funding were leaving other jobs.

Wilson (2012) uses state-level variation through an instrumental variables method to study the job effects of Recovery Act spending. His results concerning the private sector effect of the stimulus are mixed. He finds that overall employment increased as a result of the stimulus. Table 5 in his article breaks down the employment effect by sector. In one specification, he finds a statistically insignificant response of private sector employment to spending. In two others, the effect is positive and statistically significant.

Michael Grabell's (2012) book, Money Well Spent? The Truth Behind the Trillion-Dollar Stimulus, the Biggest Economic Recovery Plan in History, intended for a general audience, gives an excellent account of many aspects of the Recovery Act. It contains a detailed narrative account of why the design and execution of the stimulus led to slow and limited direct job creating/saving in the private sector, such as transportation, but rapid job creating/saving in the government sector. He also stresses the importance of the stimulus in funding social safety net programs. ${ }^{17}$

Several times per year since the beginning of the stimulus plan, the $\mathrm{CBO}$ has published a low-high interval estimate of the employment effects (combining direct and indirect jobs created/saved) of the program. In its first nine reports, the $\mathrm{CBO}$ projected that between 1.3 and 3.3 million persons would be employed in 2010 as a result of the Act; however, in its 10th report (November 2011), the $\mathrm{CBO}$ revised its estimate and reported that the Act may have created/saved as few as 650,000 jobs in 2010. Note that the CBO's jobs effect is estimated based on all components of the stimulus.

Examining the National Income and Product Accounts, Aizenman and Pasricha (2011, p. 5) find that "the federal fiscal expenditure stimulus in the U.S. during the great recession mostly compensated for the negative state and local stimuli associated with the collapsing tax revenue and the limited borrowing capacity of the states." Cogan and Taylor (2012) go even further, showing that net lending by state and local governments increased during the period they were receiving stimulus funds.

Ramey (2013), using several different specifications of structural vector autoregressions, shows that in response to an increase in government purchases, government employment rises while private sector employment falls or is unchanged. ${ }^{18}$ 


\section{APPENDIXES}

\section{Appendix A: Classification of Agencies by Intensity of Private Sector Job Creation}

As explained in the text, federal agencies awarding grants and loans to federal government organizations differ in the extent to which their funding generates creation and retention of private versus government jobs. If step $\mathrm{C}$ is reached, then I must make this assessment. ${ }^{19} \mathrm{I}$ designate three categories of federal agencies: type I-private-sector-intensive job creators; type II-equal division of private and government jobs; and type III-government-intensive job creators. An explanation for the assignment of the largest federal agencies to one of the three types follows.

\section{Type I Agencies: Private-Sector-Intensive Job Creators}

Department of Transportation (including Federal Transit Administration, Federal Highway Administration, Federal Railroad Administration)

My examination of job descriptions indicates that projects funded by the U.S. Department of Transportation resulted in mostly private sector jobs. The largest component of this funding came in the form of grants from the Federal Highway Administration to state and local government agencies, which in turn contracted construction companies. For example, in a Pavement Reconstruction and Added Capacity project by the California Department of Transportation, 289 persons were employed in widening lanes and shoulders on State Route 91 in Orange County. The corresponding recipient report's project description states "Jobs are created or retained in the construction and construction management industry such as laborers, equipment operators, electricians, project managers, support staff, inspectors, engineers, etc."

\section{Environmental Protection Agency}

My reading of the descriptions of jobs created/saved by the EPA is that most were in the construction industry. I did observe some descriptions associated with the retention of employees at state agencies charged with environmental policy.

\section{Type II Agencies: Equal Division of Job Creators}

Department of Housing and Urban Development

I classify half of the jobs created/saved by HUD as government jobs. Most of the larger awards went to state and local governments, which in turn hired or retained government employees to fill program positions. For example, the City of New York was the primary recipient of a \$74 million award from HUD as part of the Homelessness and Rapid Re-Housing program. The city reported creating and saving 380 jobs; the description of these jobs included program directors, housing specialists, community liaisons, and outreach workers. The description suggests that these were either government jobs or jobs from nonprofit organizations that help the homeless.

Note that HUD-funded awards did create many private sector jobs. The ARRA Capital Fund supported many projects that modernized existing housing and increased the stock of 
public housing. For example, these projects funded construction managers, construction workers, and engineers.

The amounts paid by local and state government agencies to these private companies would appear as payments to vendors and sub-vendors. Given that the HUD funding led to both private sector and government jobs, it is classified as 50 percent private and 50 percent public.

\section{National Institutes of Health}

Many primary recipients of NIH awards (mainly grants) were nongovernment organizations. As such, these recipients' jobs were counted as private sector in step B of the procedure. ${ }^{20}$ Among the awards to a governmental primary recipient, one of the largest in terms of job creation went to the University of Florida, which reported 32.16 jobs. Its job description field states:

Recipient (UF) funded 11.4 FTE's in various research positions required to advance the work of this project. Our 6 sub-recipients have employed 20.76 FTE's in various positions that support the work being funded under the grant.

Because a substantial number of jobs were created at the sub-recipient level, I then determined whether the sub-recipients were in government. The sub-recipients were Scripps Research Institute, The Washington University, Cornell University Inc., Ponce Medical School Foundation Inc., and the Trustees of Indiana University. Only one of these entities is a government organization. As such, I conclude that the jobs created/saved were a mix of government and private sector, with the majority in the private sector.

Another large grant went to the Research Foundation for the State University of New York, which created 26.26 jobs. In general, I treat research foundations associated with public universities as part of government for reasons detailed in the text. The job created/saved field describes these positions:

Postdoctoral Associate, Reimbursement to SUNY for faculty and staff time on research projects, Research Aide, Research Project Assistant, Research Scientist, Research Support Specialist, Research Technician I, Senior Postdoctoral Associate, Senior Research Support Specialist.

This description suggests that all or nearly all of the jobs were at the public university.

Next, the University of Miami received a grant resulting in 20.51 jobs, also one of the largest single job-creating NIH awards. The job created/saved field describes these as follows:

Prime recipient funded a quality coordinator, 3 research associates, a sr. research associate, a clinical research ooordinator, a research assistant, a sr. research analyst, a plebotomist, a sr. manager of research support, a professor, an an associate professor. Subrecipients have funded a study nurse, a research scientist, a medical investigator, a deputy health officer, 9 nurse practitioners, a sr research associate, an assistant professor, 3 associate professors, a professor, a program coordinator, 2 physicians, and 5 research assistants, a site principal investigator, a site coordinator/ research assistant, 2 reesarch assistant/counselors, a counselor, STI P.A. and a budet analyst. [Spelling errors present in original report.] 
Upon examining the sub-recipients of the award, I found that there were both private sector and government organizations.

Overall, I conclude that NIH funding to government prime recipients directly created/saved a similar proportion of private sector and government jobs, and as such it is a type II funding agency.

\section{Department of Labor}

I classify the U.S. Department of Labor as a type II agency. The California Department of Employment Development was the primary recipient of a $\$ 489$ million grant, the largest single award issued by this federal agency. The grant provided "employment services and work readiness and occupational skills training for unemployed adults and youth." The department reported creating 1,797 jobs with the description: "case managers and program support" and "hiring of youth program counselors and mentors." The award was dispersed among mostly city and county employment agencies. Thus, I infer that many jobs created were in government. A substantial fraction of the jobs created/saved also appear to be in the private sector, as both for-profit trade schools were used as sub-vendors on the grant and nonprofit organizations were sub-recipients of a fraction of the award.

The second-largest job-creating award went to the Ohio Department of Job and Family Services. The $\$ 138$ million award created 1,275 jobs with job descriptions similar to those for the California award above. The Ohio award was largely divided among sub-awardees that were mainly employment departments of various counties. Because of this split of funds, the Department of Labor is classified as a type II agency. ${ }^{21}$

Finally, only 8.3 percent of expenditures went to vendors and sub-vendors, and only 2.4 percent of expenditures were made through federal contracts.

\section{Type III Agencies: Government-Intensive Job Creators}

\section{Department of Education: Office of Elementary and Secondary Education}

I classify the Department of Education as creating mostly government jobs. The largest part of this department's funding came as State Fiscal Stabilization Fund education grants. These grants were intended to mitigate and avoid state and local cutbacks in education as well as improve instruction.

In terms of parsing the jobs created by this funding, California's jobs descriptions from education awards are particularly useful. California's main Education Fund grant was a \$4.39 billion award, of which it had spent $\$ 3.95$ billion by the quarter I consider. It was California's largest job-creating grant, with 35,393 jobs created and saved; most importantly, its job description provided a useful quantitative breakdown of the jobs. In particular, its description listed 287 jobs as vendor jobs. Thus, less than 1 percent of the jobs created were vendor jobs. Of the remaining jobs, 16,208 were precollege teaching positions and 3,547 were nonteaching positions, including food service, bus drivers, teaching assistants, custodians, office staff, librarians, and instructional aides. The remaining jobs were at public postsecondary schools, the University of California system, the California State University system, and the California Community Colleges System. 
I note that the Recovery Act allowed the education state grants to be used for infrastructure improvements to a state's schools. Significant private sector job creation could have come from large infrastructure investment. I do not see this in the data, at least through the quarter studied. In California, only $\$ 8.1$ million of the $\$ 3.95$ billion from this grant was spent on infrastructure. ${ }^{22}$

Ohio's main Education Fund grant was a $\$ 1.46$ billion award, of which it had spent $\$ 523$ million by the quarter I consider and created 8,465 jobs. The Ohio Department of Transportation provided me with a very detailed breakdown of the jobs created for Ohio's ARRA funds. It includes job descriptions from every school, self-reported by each school's staff. ${ }^{23}$ Inspection of the breakdown indicates that nearly all of the jobs went to public school employees: teachers, aides, principals, librarians, and so on.

Department of Education: Office of Special Education and Rehabilitation Services

The U.S. Department of Education administered Special Education grants to states through its Office of Special Education and Rehabilitative Services. This office funded a total of 62,891 jobs. ${ }^{24}$ My inspection of the job descriptions for a group of grants to these states indicates that nearly all were for professional and support staff in public education.

The State of California reported creating/saving 5,722 jobs from its Special Education grant. Its job description (listed as FTEs) follows:

Jobs created or retained include 3164.86 classified jobs, 2360.90 certificated jobs, 193.81 vendor jobs, and 0.00 IHE [Institutions of Higher Education] jobs. Classified jobs include non-teaching positions such as food service, bus drivers, teacher assistants, custodians, office staff, librarians, and instructional aides for special education. Certificated jobs include teaching positions. Vendor jobs represent a variety of different types of jobs.

Nearly every sub-recipient on the grant was a city government, county government, or school district.

The Georgia Department of Education was awarded a Special Education grant of $\$ 314$ million. It reported creating/saving 2,522 jobs. Its job description (listed as FTEs) states:

Teachers (693.30); Aides \& Paraprofessionals (1528.57); Clerical Staff (27.95); Interpreter (2.63); Technology Specialist (4.00); School Nurse (2.69); Physical Therapist (5.50); Teacher Support Specialist (55.47); Secondary Counselor (3.00); School Psychologist (22.33); School Social Worker (3.91); Family Services/Parent Coordinator (5.00); Bus Drivers (57.30); Other Management (21.07); Other Administration (89.79); Other Salaries \& Compensation (11.38); Speech Language Therapist (2.95); Other (15.26)

\section{Department of Justice}

I classify jobs funded by the Department of Justice as mostly in the government sector (i.e., type III). The Department of Justice administered Justice Assistance Grants (JAG) to states and some localities. In reading many descriptions of projects and the jobs created by those projects from the recipient reports, I observe that most of the jobs are in law enforcement, the courts, and jail coverage.

For example, the state of Virginia's recipient report stated the funds "afforded the state legislature the opportunity to offset the budget cuts necessitated by declining state revenues. 
The Recovery Act JAG funds will be used to provide funds to the Compensation Board for distribution to Sheriff's offices during state fiscal year 2010." Virginia distributed most of its award among a total of 121 city governments, county governments, and (a few) jails. It created/saved 1,789 jobs and listed the following description:

\$23.2 million in Federal funds were used this quarter to offset the State budget cuts. Deputies in 144 Sheriff's offices across the Commonwealth were able to retain employment. While the number of jobs retained may seem a little unusual, the entire \$23.2 million dollars was expended in one quarter and not spread over the year as projected in our grant application.

In terms of jobs created, the second-largest grant from the Department of Justice was awarded to the Ohio Office of Criminal Justice Services. It reported creating/saving 398.84 positions (it did not report these as FTEs). The corresponding job description suggests that most of these jobs were in government:

Description of ARRA JAG jobs created: Courts/prosecution/defense/civil attorney 10; Law enforcement 44; Info technology 5; Community/social/victim service 101; Training/technical assistance 6; Detention/probation/parole/comm corrections 38; Administrative/human resources 10; Construction 1; Policy/Research/Intelligence 11.

Description of ARRA JAG jobs retained: Courts/prosecution/defense/civil attorney 24; Law enforcement 121; Info technology 1; Community/social/victim service 183; Training/technical assistance 1; Detention/probation/parole/comm corrections 51; Administrative/human resources 28; Construction 6; Policy/Research/Intelligence 12.

Hennepin County in Minnesota received a JAG award of \$5.7 million and reported 88.9 jobs saved. The description of these jobs stated that they were "all law enforcement" and "all retained." As further evidence, only 3.6 percent of all expenditures was paid to vendors and subvendors. 
Table A1

Examples of Strings Indicating ARRA Recipient as a Private Sector Organization or Business

JV

ARCHITEC

FOUNDATION

INCORPOR

CONSTRUCTION

CO.

CATHOLIC

PHARM

LLC

L.L.C.

LTD

UNITED WAY

HABITAT FOR HUMANITY

BIG SISTERS

ASSOCIATES

BETH ISRAEL

PUBLIC/PRIVATE VENTURES

UNIVERSITY OF CHICAGO, THE

UNIVERSITY OF NOTRE DAME DU LAC

UNIVERSITY OF SAN DIEGO
JOINT VENTURE

CONSTRUCT

CORPORATION

CORP.

ENGINEERING

CHRISTIAN

COMPANY

(INC)

(INC.)

Inc

COMP.

GOODWILL

BIG BROTHERS

METHODIST

BUILDERS

SEMINARY

ONESTAR NATIONAL SERVICE COMMISSION

UNIVERSITY OF LA VERNE

UNIVERSITY OF ROCHESTER

UNIVERSITY OF SOUTHERN CALIFORNIA

NOTE: These are 40 of the 542 strings used to identify private sector organizations and businesses used in step C in this article's algorithm.

\section{Table A2}

\section{Examples of Strings Indicating ARRA Recipient as a Government Organization}

CITY OF

COUNTY

PARISH

DEPT

AUTHORITY

DEPART

DEPARTMENT

TOWNSHIP

HOUSING COMMISSION

AGENCY

DISTRICT

RAPID TRANSIT

AIRPORT

OFFICE OF

VILLAGE

SECRETARY OF

BOARD OF

DISTRICT

BOROUGH OF

STATE

TOWN OF

DIVISION OF

GOVERNOR

ADMINISTRATION

TOWNSHIP

MUNICIPALITY

CITY HALL

HIGHWAY PATROL

PUBLIC SAFETY

PUBLIC INSTRUCTION

COMMUNITY COLLEGE

COMMONWEALTH

NEW JERSEY TRANSIT

TRIBE

TRIBAL COUNCIL

CHEROKEE NATION

SIOUX NATION

HOUSING COMMISSION

ATTORNEY GENERAL

NATIONAL GUARD

NOTE: These are 40 of the 430 strings used to identify government organizations and businesses used in step C in this article's algorithm. 


\section{Table A3}

\section{Federal Agencies Funding ARRA Grants and Loans: Numbers of Jobs Created/Saved in First Quarter of 2010 and Intensity of Private Sector Job Creation}

Office of Elementary and Secondary Education

394,740

Office of Special Education and Rehabilitative Services

62,891

Department of Housing and Urban Development

19,061

Administration for Children and Families

17,828

Federal Highway Administration

16,769

Department of Labor

16,347

National Institutes of Health

16,199

Department of Energy

15,408

Department of Justice

15,152

Federal Transit Administration

12,922

Department of Education

11,667

Environmental Protection Agency

9,292

Corporation for National and Community Service $\quad 7,327$

Health Resources and Services Administration

7,043

National Science Foundation

3,565

Federal Aviation Administration

1,992

Forest Service

Rural Utilities Service

National Endowment for the Arts

1,546

1,366

1,364

1,219

Assistant Secretary for Public and Indian Housing

1,035

Department of Health and Human Services

Federal Railroad Administration

Department of the Army

Bureau of Reclamation

Rural Housing Service

Maritime Administration

Centers for Disease Control and Prevention

U.S. Army Corps of Engineers-Civil Program Financing Only

Administration on Aging

Office of Science

Indian Health Service

Indian Affairs (Assistant Secretary)

National Oceanic and Atmospheric Administration

Community Development Financial Institutions

National Telecommunication and Information Administration

Employment and Training Administration

Food and Nutrition Service

Economic Development Administration

Department of the Interior

National Aeronautics and Space Administration

Rural Business-Cooperative Service

U.S. Fish and Wildlife Service

Federal Emergency Management Agency

836

601

562

513

499

495

487

487

392

345

334

319

200

197

179

159

144

139

135

123

110

107

III

II

I

I

I

I

II

I

I

I

II

I

I

I

II

I

II

I

II

II

I

II

II

I

II

II

II

NOTE: Type I, private-sector-intensive; type II, equal division between private and government sectors; type III, government-sector-intensive. Excludes federal agencies creating fewer than 50 jobs.

SOURCE: Recipient reports available at http://recovery.gov. 


\section{Appendix B: Recovery Board Definition of a Job Created or Retained}

The RATB's definition of a saved (i.e., retained) job or a created job is dependent on the reporting instructions provided to recipients. These instructions differed slightly between recipients of contracts and recipients of grants or loans. I discuss the grants and loans rules first.

FederalReporting.gov, along with the $\mathrm{OMB}$, provided instructions to recipients of grants and loans for calculating the number of jobs created or saved. While recipients have several pages of guidance for calculating a jobs created/retained number, the following paragraph from OMB (2009) summarizes the key aspects:

\footnotetext{
The estimate of the number of jobs created or retained by the Recovery Act should be expressed as "full-time equivalents" (FTE). In calculating an FTE, the number of actual hours worked in funded jobs are divided by the number of hours representing a full work schedule for the kind of job being estimated. These FTEs are then adjusted to count only the portion corresponding to the share of the job funded by Recovery Act funds. Alternatively, in cases where accounting systems track the billing of workers' hours to Recovery Act and non-Recovery Act accounts, recipients may simply count the number of hours funded by the Recovery Act and divide by the number of hours in a full-time schedule.
}

The OMB (2010) gives very similar instructions for reporting jobs created and retained to recipients of ARRA contracts. One distinction made for contractors that does not hold for grant and loan recipients is as follows: "The definition applies to prime contractor positions and first-tier subcontractor positions where the subcontract is $\$ 25,000$ or more." Moreover, all primary recipients were instructed to not report the employment impact on materials suppliers and central service providers (referred to as "indirect" jobs) or on the local community (referred to as "induced" jobs).

OMB (2010) goes on to say:

"Job Created" means those new positions created and filled, or previously existing unfilled positions that are filled, that are funded by the American Recovery and Reinvestment Act of 2009 (Recovery Act). This definition covers only positions established in the United States and outlying areas (see definition in FAR 2.101). The term does not include indirect jobs or induced jobs. "Job Retained" means those existing filled positions that are funded by the American Recovery and Reinvestment Act of 2009 (Recovery Act). 


\section{NOTES}

1 President Barack Obama signed the Recovery Act during his first month in office. For an early outline of the plan, see Summers (2008). For an early projected impact of the plan, see Bernstein and Romer (2009).

2 See CBO (2011).

3 At the time this article was written, the data were available for download at the website Recovery.gov. The site also contained a data user guide; see Recovery Accountability and Transparency Board (2009).

4 Unless otherwise stated, jobs reported in the text as saved/created are FTEs and are shown as rounded numbers. As a result, they may differ from the exact values in the tables.

5 At the one-year mark, the Act's funding directed toward grants, contracts, and loans totaled $\$ 83.6$ billion. Note that there are no recipient-reported jobs data for other ARRA spending because such spending does not create/ save jobs directly.

6 U.S. House of Representatives (2011).

7 See page 2 of Bernstein and Romer (2009).

8 Note that Bernstein and Romer's number is not directly comparable with my results because they did not include what they call both direct and indirect employment creation in this quote. I have not found precise definitions of "direct" versus "indirect" job creation in the existing literature.

9 The above numbers refer to point estimates from the respective studies.

10 Section 1512 of the ARRA.

${ }^{11}$ The data description was slightly different in the first quarterly reporting period. At that time, recipients were asked to construct a jobs number based on whether a given job would have existed were it not for the Recovery Act. The reason for the change was the subjective nature of the original question. I did not use the first-quarter responses in my study.

${ }^{12}$ The most likely reason that a sub-recipient was in the private sector was because it is a nonprofit organization.

${ }^{13}$ In designing the entire procedure, I tried to minimize (to the greatest amount possible) the discretion (i.e., "judgment calls") needed to categorize jobs as being in the private or government sectors. Step C required the most discretion on my part since the time that would be required to partition individual jobs into the private or government sectors on an award-by-award basis was prohibitive.

${ }^{14}$ See Appendix A for a description of type II projects.

15 See Figure 1 in Bernstein and Romer (2009).

${ }^{16}$ If the created and saved jobs were in relatively healthy parts of the job market, then one would expect to see a substantial number of Recovery Act job takers coming from other jobs. To this point, Jones and Rothschild (2011) survey findings have shown that approximately one-half of the individuals filling positions directly created by the ARRA were leaving other jobs.

${ }^{17}$ Note that Grabell's overall assessment is that the stimulus may have created/saved millions of jobs (direct plus indirect), which is consistent with some estimates by others, such as the president's Council of Economic Advisers (2010).

${ }^{18}$ The horizon of Ramey's study does not include the ARRA period.

${ }^{19}$ Recall that step $\mathrm{C}$ is reached if the award is not a contract and the primary recipient's name indicates it is a nonfederal government organization.

${ }^{20}$ Recall that in step B, if the primary recipient has a name indicating that it is in the private sector, then its jobs are assigned to the private sector.

21 The distinction between government and nongovernment can become muddled with respect to employment services. For example, the largest sub-recipient of the Ohio award is the Central Ohio Workforce Investment Corporation. It has partners in the private sector, such as Goodwill of Ohio. It satisfies this article's definition of a type II agency because, as its website states, its "Board [is appointed] by the Mayor of the City of Columbus and 
the Franklin County Board of Commissioners, in conjunction with recommendations made by the Greater Columbus Chamber of Commerce."

22 The recipient survey includes several questions about infrastructure spending in particular.

23 These data are a matter of public record and are available from the author on request.

${ }^{24}$ This total includes Special Education and other grants that it administered.

\section{REFERENCES}

American Recovery and Reinvestment Act. Public Law 111-5, 111th Congress, February 17, 2009; http://www.gpo.gov/fdsys/pkg/PLAW-111publ5/pdf/PLAW-111publ5.pdf.

Aizenman, Joshua and Pasricha, Gurnain K. "The Net Fiscal Expenditure Stimulus in the U.S., 2008-9: Less than What You Might Think, and Less than the Fiscal Stimuli of Most OECD Countries." The Economists' Voice, June 2011, 8(2), pp. 1-6.

Bernstein, Jared and Romer, Christina. "The Job Impact of the American Recovery and Reinvestment Plan." Council of Economic Advisers and Office of the Vice President Elect, January 9, 2009; http://otrans.3cdn.net/45593e8ecbd339d074_I3m6bt1te.pdf.

Blinder, Alan S. After the Music Stopped: The Financial Crisis, the Response, and the Work Ahead. New York: Penguin Books, 2013.

Cogan, John F. and Taylor, John B. "What the Government Purchases Multiplier Actually Multiplied in the 2009 Stimulus Package," in Lee E. Ohanian, John B. Taylor, and lan Wright, eds., Government Policies and the Delayed Economic Recovery. Chap. 5. Stanford, CA: Hoover Institution Press, 2012, pp. 85-114.

Cohen, Lauren; Coval, Joshua and Malloy, Christopher. “Do Powerful Politicians Cause Corporate Downsizing?" Journal of Political Economy, December 2011, 119(6), pp. 1015-60.

Congressional Budget Office. "The Budget and Economic Outlook: Fiscal Years 2011 to 2021." January 2011; http://www.cbo.gov/sites/default/files/cbofiles/ftpdocs/120xx/doc12039/01-26_fy2011outlook.pdf.

Conley, Tim and Dupor, Bill. "The American Recovery and Reinvestment Act: Solely a Government Jobs Program?" Journal of Monetary Economics, July 2013, 60(5) pp. 535-49.

Council of Economic Advisers. "The Economic Impact of the American Recovery and Reinvestment Act of 2009: Third Quarterly Report." Executive Office of the President, April 14, 2010; http://www.whitehouse.gov/sites/default/files/microsites/CEA-3rd-arra-report.pdf.

Gandel, Stephen. “After One Year, a Stimulus Report Card." Time, February 17, 2010; http://content.time.com/time/specials/packages/article/0,28804,1964765_1964764_1964758,00.html.

Government Accountability Office. “Recovery Act: Recipient Reported Jobs Data Provide Some Insight into Use of Recovery Act Funding, but Data Quality and Reporting Issues Need Attention." GAO-10-223, November 19, 2009; http://www.gao.gov/assets/300/298632.pdf.

Government Accountability Office. "Recovery Act: Progress and Challenges in Spending Weatherization Funds." GAO-12-195, December 16, 2011; http://www.gao.gov/assets/590/587064.pdf.

Grabell, Michael. Money Well Spent? The Truth Behind the Trillion-Dollar Stimulus, the Biggest Economic Recovery Plan in History. New York: PublicAffairs, 2012.

Greenfield, Stuart. "Public Sector Employment: The Current Situation.” Working paper, Center for State and Local Government Excellence, 2007.

Jacobson, Louis. "Government Jobs vs. Private Jobs: Which Help the Economy More?" Tampa Bay Times, February 23, 2013; http://www.tampabay.com/news/business/economicdevelopment/government-jobs-vs-private-jobswhich-help-the-economy-more/1276248.

Jones, Garrett and Rothschild, Daniel M. "Did Stimulus Dollars Hire the Unemployed? Answers to Questions about the American Recovery and Reinvestment Act." Working Paper No. 11-34, Mercatus Center, George Mason 
University, September 2011; http://mercatus.org/sites/default/files/publication/Did_Stimulus_Dollars_Hire_ The_Unemployed_Jones_Rothschild_WP34.pdf.

Office of Management and Budget. "Memorandum for the Heads of Executive Departments and Agencies. Updated Guidance on the American Recovery and Reinvestment Act-Data Quality, Non-Reporting Recipients, and Reporting of Job Estimates." Executive Office of the President, December 18, 2009; http://www.whitehouse.gov/sites/default/files/omb/assets/memoranda_2010/m10-08.pdf.

Office of Management and Budget. "Recovery FAQs for Federal Contractors on Reporting." July 2, 2010; http://www.whitehouse.gov/omb/recovery_faqs_contractors.

Ramey, Valerie A. "Government Spending and Private Activity," in Alberto Alesina and Francesco Giavazzi, eds., Fiscal Policy after the Financial Crisis. Chap. 1. Chicago: University of Chicago Press, 2013, pp. 19-55.

Recovery Accountability and Transparency Board. "Recovery.gov: Download Center User Guide." Recovery.Gov, 2009; http://www.recovery.gov/arra/FAQ/OtherDLFiles/Download\%20Center\%20User\%20Guide.pdf.

Recovery Accountability and Transparency Board. "Recipient Reporting Data Model v4.0: Final Production Release, for Quarter Ending September 30, 2010." Recovery.Gov, 2010; http://billdupor.weebly.com/uploads/2/2/8/0/22808472/fedrptgdatamodel_v4.0.pdf.

Shapiro, Matthew D. and Slemrod, Joel. "Did The 2001 Tax Rebate Stimulate Spending? Evidence From Taxpayer Surveys," in James M. Poterba, ed., Tax Policy and the Economy. Volume 17. Cambridge, MA: MIT Press, 2003, pp. 83-110.

Shapiro, Matthew D. and Slemrod, Joel. "Did the 2008 Tax Rebates Stimulate Spending?" American Economic Review, May 2009, 99(2), pp. 374-79.

Summers, Larry. “The Economic Recovery PlanPolicy Work," in a memo to President-Elect Obama, December 15, 2008; http://s3.documentcloud.org/documents/285065/summers-12-15-08-memo.pdf.

U.S. House of Representatives. "Economists' Statement to President Obama." [Letter from John A. Boehner to President Barack Obama.] February 13, 2011;

http://www.speaker.gov/sites/speaker.house.gov/files/UploadedFiles/Boehner-Obama-Letter-2-13-11-1.pdf.

Wilson, Daniel J."Fiscal Spending Jobs Multipliers: Evidence from the 2009 American Recovery and Reinvestment Act." American Economic Journal: Economic Policy, August 2012, 4(3), pp. 251-82. 
